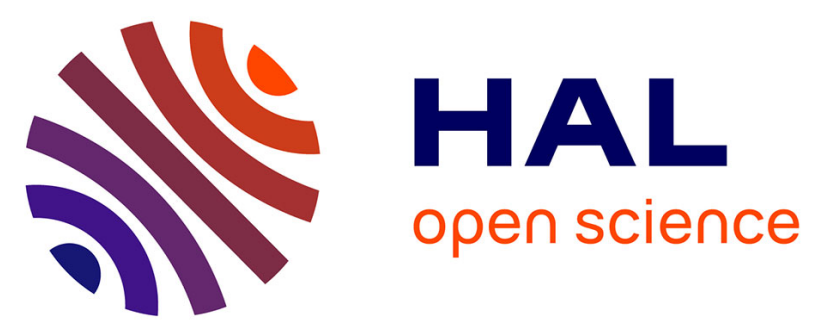

\title{
Light interception characteristics estimated from three-dimensional virtual plants for two apple cultivas and influenced by combinations of rootstocks and tree architecture in loess plateau of China
}

Weiwei Yang, Xilong Chen, M. Saudreau, Manrang Zhang, Chenxi Gao, Hangkong Liu, Evelyne Costes, Mingyu Hang

\section{To cite this version:}

Weiwei Yang, Xilong Chen, M. Saudreau, Manrang Zhang, Chenxi Gao, et al.. Light interception characteristics estimated from three-dimensional virtual plants for two apple cultivas and influenced by combinations of rootstocks and tree architecture in loess plateau of China. X. International Symposium on Modelling in Fruit Research and Orchard Management, Jun 2015, Montpellier, France. , Acta Horticulturae, 1160, pp.53, 2015, 10.17660/ActaHortic.2017.1160.36 . hal-01269060

\author{
HAL Id: hal-01269060 \\ https://hal.science/hal-01269060
}

Submitted on 2 Jun 2020

HAL is a multi-disciplinary open access archive for the deposit and dissemination of scientific research documents, whether they are published or not. The documents may come from teaching and research institutions in France or abroad, or from public or private research centers.

$$
\text { Copyright }
$$

L'archive ouverte pluridisciplinaire HAL, est destinée au dépôt et à la diffusion de documents scientifiques de niveau recherche, publiés ou non, émanant des établissements d'enseignement et de recherche français ou étrangers, des laboratoires publics ou privés. 
S6-1

\title{
LIGHT INTERCEPTION CHARACTERISTICS ESTIMATED FROM THREE-DIMENSIONAL VIRTUAL PLANTS FOR TWO APPLE CULTIVARS AND INFLUENCED BY COMBINATIONS OF ROOTSTOCKS AND TREE ARCHITECTURE IN LOESS PLATEAU OF CHINA
}

\author{
Dr. Weiwei Yang, No.3 Taicheng Road, NWSUAF, South Campus, College of \\ Horticulture, Yangling, Shaanxi, 712100, China (presenting author) \\ Xilong Chen, No.3 Taicheng Road, NWSUAF, South Campus, College of \\ Horticulture, Yangling, Shaanxi, 712100, China (co-author) \\ Dr. Marc Saudreau, UMR547, PIAF, INRA, UNIV BLAISE PASCAL, 63100 \\ Clermont-ferrand, France (co-author) \\ Prof. Dr. Manrang Zhang, No.3 Taicheng Road, NWSUAF, Yangling, \\ Shaanxi, 712100, China (co-author) \\ Chenxi Gao, No.3 Taicheng Road, NWSUAF, South Campus, College of \\ Horticulture, Yangling, Shaanxi, 712100, China (co-author) \\ Dr. Hangkong Liu, No.3 Taicheng Road, NWSUAF, South Campus, College \\ of Horticulture, Yangling, Shaanxi, 712100, China (co-author) \\ Dr. Evelyne Costes, av. Agropolis, TA A-10803, 34398 Montpellier, France \\ (co-author) \\ Prof. Dr. Mingyu Hang, No.3 Taicheng Road, NWSUAF, South Campus, \\ College of Horticulture, Yangling, Shaanxi, 712100, China (co-author)
}

The performance of dwarf rootstock and tall spindle training system (DT) in apple high density orchard depends on the local environment. The agronomic efficiency of DT is presently under debate in China where almost $90 \%$ of apple orchards use vigorous rootstock, even in high density orchard, usually combined with free spindle training system (VF). The objective of this study was compare DT and VF efficiencies for two apple cultivars, Fuji and Gala, in the conditions of Loess Plateau of China. For this, we digitized 2 or 3 trees of each cultivar on which we estimated light interception at the tree scale as well as light partitioning between shoot types. All trees were digitized at annual shoot scale before harvest in 2011 and 2012. Shoots were distinguished according to length (long and short) and type (fruiting or vegetative). Virtual canopies were reconstructed based on allometric relationships and leaf angle distributions sampled at shoot and leaf scale in each year. Total leaf area, projected leaf area and direct and diffuse silhouette to total leaf area (STAR) were estimated at the tree scale with the VegeSTAR software, without taking into account the effect of neighbour trees. At tree scale, DT significantly improved both the diffuse and direct light interception compared to VF, Fuji being less efficient in VF than Gala. No differences were found for light partitioning among shoot types between DT and VF. For both treatments, vegetative shoots had the highest STAR, followed by fruiting shoots, vegetative short shoots having the lowest values. The precise assessment of light interception between DT and VF helped us to compare the differences between the two planting systems and their performance for light interception 